\title{
生息魚種の多様性を支える河道物理特性 に関する研究 \\ A STUDY ON PHYSICAL FEATURE OF RIVER CHANNEL WHICH SUPPORTING THE DIVERSITY OF KINDS OF FISHES
}

\author{
砂田憲吾 1 ・ 川村和也 2 \\ Kengo SUNADA, Kazuya KAWAMURA \\ 1フェロー会員 工博 山梨大学大学院 教授 医学工学総合研究部（テ400-8511 甲府市武田4-3-11） \\ 2 学生会員 山梨大学大学院 工学研究科（广400-8511 甲府市武田4-3-11）
}

\begin{abstract}
In this study, quantitative analysis on the relation between the physical diversity of river channel and the diversity of kinds of fishes has been carried out.

In this paper, the authors tried to find the physical factor of river channel which had an influence effectively to preserve the diversity of kinds of fishes by increasing the rivers and areas to analyze it, in addition to the results until now. The diversity of kinds of fishes was assessed by using the Simpson's diversity index. On the other hand, the diversity of river channel was expressed by standard deviations of the channel hydraulic variables, such as water depth and flow velocity.

The results of this examination showed that the diversity of kinds of fishes was secured in the area which the diversity of kinds of the young fishes was rich. And, as for the rate of the area of the shoreline, it found that it was important as well as "riffle and pool" which was important in the existent research.
\end{abstract}

Key Words : diversity of kinds of fishes, physical diversity of river channel, riffle-pool-shoreline

\section{1. はじめに}

近年における生物多様性保全の問題については, 平成 14年 3月に地球環境保全に関する関係閣僚会議において 決定された「新・生物多様性国家戦略」に見られるよう に，国政レベルでの取組みがなされるようにまでなって きた. これまでの魚類を対象とした河川生態に関する研 究では, 個々の魚種が選好性を示す微小な生息場に関す る評価や特定魚種にとっての良好な生息環境に関する調 查などが主で, 各々の点で多くの成果が得られてきてい る. しかし，実際の河川における生息環境は，種間競争 や採餌などの生態系としての複雑な要因が絡み合い，特 定された魚種にとっての選好性を表すのみでは, 生態系 からみた魚類にとっての健全な生息場を保全することに は繋げにくい，そこで，本研究ではこの点に着目し，魚 類を中心とした生物多様性保全について, 複雑な河道環 境が生息生物の多様度を支える基礎となるという考えか ら，生息魚種および河道の物理環境の多様性を定量的に 表し，生息場としての評価を目指してきている ${ }^{1)}$.

これまでの検討では，一級河川富士川を対象として，
水深と流速の断面内標準偏差を用いて評価区間内におけ る瀬・淵と判断できる構造をある程度示すことができ， 同時に，そのような瀬・淵を有する河道区間には，多様 な魚種の存在も確認された. 一方, 瀬・淵構造が定量的 にも表れてこない河道区間には，優占種の存在が際立ち， 生息魚類の多様性も低い結果となった。 また，これらに 加え, 魚類の成長段階としての仔稚魚期の生息に必要と される水際域の存在が，生息魚種および河道の物理的多 様性を支えるために重要であることも指摘できた ${ }^{1)}$.

ここで今回は, 日本の他の河川についても同様の解析 を詳細に行い，実際の川づくりや魚類を含む生態系保全 のための指標となりうる生物多様性保全に対する河道物 理環境の評価を試みることを目的とした.

\section{2. 対象とする河川および調査区間について}

本研究では, これまでの一級河川富士川に，天竜川上 流域, 太田川を新たに加えた計3河川を解析対象とした. これは，1つの水系において国勢調査の行われた区間毎 の違いを知るための魚類データなどの基礎情報を, より 
表-1. 解析対象とした河川水辺の国勢調査区間の概要

\begin{tabular}{|c|c|c|c|c|c|c|c|}
\hline $\begin{array}{l}\text { 河 } \\
\text { 川 } \\
\text { 名 }\end{array}$ & $\begin{array}{l}\text { 記 } \\
\text { 号 }\end{array}$ & 地区名 & $\begin{array}{c}\text { 調査区間 } \\
\text { (基淮点から } \\
\text { の距離;km) }\end{array}$ & $\begin{array}{l}\text { 河休 } \\
\text { 勾配 }\end{array}$ & $\begin{array}{l}\text { 河川 } \\
\text { 形態 }\end{array}$ & $\begin{array}{c}\text { 搅捕 } \\
\text { 魚種数 }\end{array}$ & 採捕数 \\
\hline \multirow{4}{*}{$\begin{array}{l}\text { 富 } \\
\pm \\
\text { 川 }\end{array}$} & $\mathrm{F} 1$ & 蓬莱橋 & $9.5^{\sim} 10.5$ & $1 / 247$ & $\mathrm{Bb}$ & 15 & 364 \\
\hline & F2 & 南部橋 & $29.5^{\sim} 30.0$ & $1 / 236$ & $\mathrm{Bb}$ & 15 & 470 \\
\hline & F3 & 富士橋 & $62.0^{\sim} 63.0$ & $1 / 722$ & $\mathrm{Bb}$ & 11 & 1245 \\
\hline & F4 & 信玄橋 & $76.5^{\sim} 77.6$ & $1 / 141$ & $\mathrm{Bb}$ & 10 & 371 \\
\hline \multirow{12}{*}{$\begin{array}{l}\text { 天 } \\
\text { 竜 } \\
\text { 川 } \\
\text { 上流 }\end{array}$} & $\mathrm{T} 1$ & 飯田市水神橋 & $144.0^{\sim} 144.9$ & $1 / 99$ & $\mathrm{Bb}$ & 19 & 1080 \\
\hline & $\mathrm{T} 2$ & 南大島川合流 & $149.3^{\sim} 150.1$ & $1 / 192$ & $\mathrm{Bb}$ & 14 & 447 \\
\hline & T3 & 田沢川合流 & $155.7^{\sim} 156.2$ & $1 / 190$ & $\mathrm{Bb}$ & 23 & 774 \\
\hline & $\mathrm{T} 4$ & 天の中川橋 & $164.0^{2} 164.3$ & $1 / 210$ & $\mathrm{Bb}$ & 19 & 699 \\
\hline & T5 & 坂戸橋 & $169.0^{2} 169.3$ & $1 / 125$ & $\mathrm{Bb}$ & 12 & 571 \\
\hline & T6 & 小鍛冶橋 & $178.5^{\sim} 178.8$ & $1 / 355$ & $\mathrm{Bb}$ & 16 & 287 \\
\hline & T7 & 天竜大橋 & $181.2^{2} 181.5$ & $1 / 173$ & $\mathrm{Bb}$ & 18 & 548 \\
\hline & T8 & 北の城橋 & $185.4^{\sim} 185.7$ & $1 / 163$ & $\mathrm{Bb}$ & 18 & 536 \\
\hline & T9 & 伊那市水神橋 & $195.5^{\sim} 195.8$ & $1 / 262$ & $\mathrm{Bb}$ & 15 & 531 \\
\hline & $\mathrm{T} 10$ & 大泉川合流 & $197.4^{\sim} 197.7$ & $1 / 262$ & $\mathrm{Bb}$ & 16 & 411 \\
\hline & $\mathrm{T} 11$ & 柿ノ木淵 & $204.1^{\sim} 204.5$ & $1 / 250$ & $\mathrm{Bb}$ & 15 & 346 \\
\hline & $\mathrm{T} 12$ & 横川川合流 & $212.3^{\sim} 212.8$ & $1 / 240$ & $\mathrm{Bb}-\mathrm{Bc}$ & 12 & 295 \\
\hline \multirow{6}{*}{$\begin{array}{l}\text { 太 } \\
\text { 田 } \\
\text { 川 }\end{array}$} & $\mathrm{O} 1$ & 東野 & $10.7^{\sim} 11.1$ & $1 / 620$ & $\mathrm{Bb}$ & 23 & 445 \\
\hline & $\mathrm{O} 2$ & 高瀬堰下流 & $12.8^{\sim} 13.3$ & $1 / 620$ & $\mathrm{Bb}$ & 23 & 402 \\
\hline & O3 & 玫村 & $14.8^{\sim} 15.4$ & $1 / 620$ & $\mathrm{Bb}$ & 20 & 497 \\
\hline & $\mathrm{O} 4$ & 共栄橋 & $26.1^{2} 26.3$ & $1 / 890$ & $\mathrm{Bb}$ & 18 & 282 \\
\hline & O5 & 附地堤堤 & $52.0^{\sim} 52.2$ & $1 / 150$ & $\mathrm{Bb}$ & 9 & 234 \\
\hline & O6 & 土居橋 & $67.0^{\sim} 67.4$ & $1 / 100$ & $\mathrm{Aa}-\mathrm{Bb}$ & 15 & 267 \\
\hline
\end{tabular}

多く集めることができる河川であったこと，また河川の 地域性やそこに生息する魚種などに違いを持たせること で, 生息魚種と河道の物理特性との関係をより明らかに 表すことができるのではないかと考えたからである．ま た，今回もこれまでと同様に河川淡水魚に着目するので， 汽水海水魚が多く存在する感潮区間については対象から 外した。この結果, 富士川（4地点）, 天竜川上流（12 地点・なお河道断面については11地点），太田川（6地 点）の合計22地点を解析対象とした. 表-1に, 河川名, 調査地点, 基準点からの距離, 区間距離, 省略記号, 河 道形態，魚種数，総採捕個体数などの一覧を示す.

\section{3. 多様性の算出結果}

\section{（1）生息魚種の多様性}

生息魚種の多様性を算出する際の基礎データとして, 本研究では解析対象となる河川において実施された河川 水辺の国勢調查（魚類）結果を使用した. この調查時期 としては主に春〜秋にかけて年 2 回実施され，投網回数 や採捕条件の面でも配慮されており, 結果は信頼できる と考えた. 各々の調査年は, 富士川（1998年），天竜川 （2002年），太田川（2000年）である. またこの調査で は，採捕魚種の体長区分もなされており，ここから，一 般的に知られる採捕魚種の成長状況を調べることによっ て，成魚もしくは仔稚魚を含む未成魚の同定を行い，各 調査区間が，様々な生息魚種の成長段階別にみた多様性 に対応できているかの判断も試みた. よって，本研究に おける生息魚種の多様性の分類方法としては, (1)各調査 区間において採捕された全魚種についての評価，(2)採捕 魚の体長区分による成魚, 未成魚からの評価, という2 つについて考えた．また，生息魚種の多様性を表す定量 的指標としては, Simpson多様度を使用し, 解析対象と なる全ての調査区間での計算結果を図一1に示す.

\section{Simpson多様度 $=1-D, D=\Sigma n_{i}\left(n_{i}-1\right) / N(N-1)$}

ここに, $n_{i}$; 採捕地点における種 $i$ の個体数, $N$; 採 捕地点における総個体数である. また, $0 \leqq 1-D \leqq 1$ で表され，1に近いほど，その地域は多様性に富んだ魚 類群集を構成していると考えることができる.

この結果から，今回解析対象とした一級河川の調查場 所に限れば，F3（富士川一富士橋周辺）の結果を除き， 全体的に生息魚種の多様性が高いことがわかる。つまり， ほとんどの区間において，限られた優占種のみにとって 選好性のある生息場所を整えているというわけではなく， ある程度は生息魚種の均衡性が保たれていることが伺え る. また特に, 図一2に表すように，未成魚についての 多様性と採捕総個体数についての多様性との間に, 相関

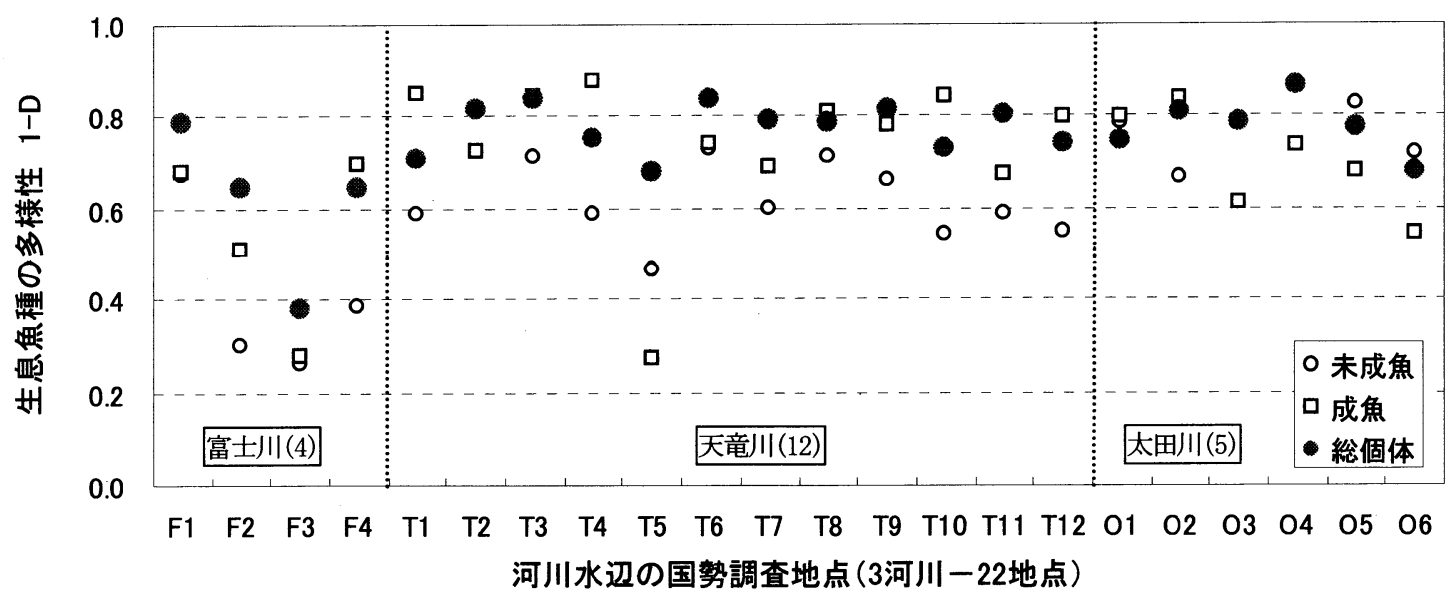

図一1. 解析対象とした河川水辺の国勢調査区間における生物多様性指数計算結果分布 


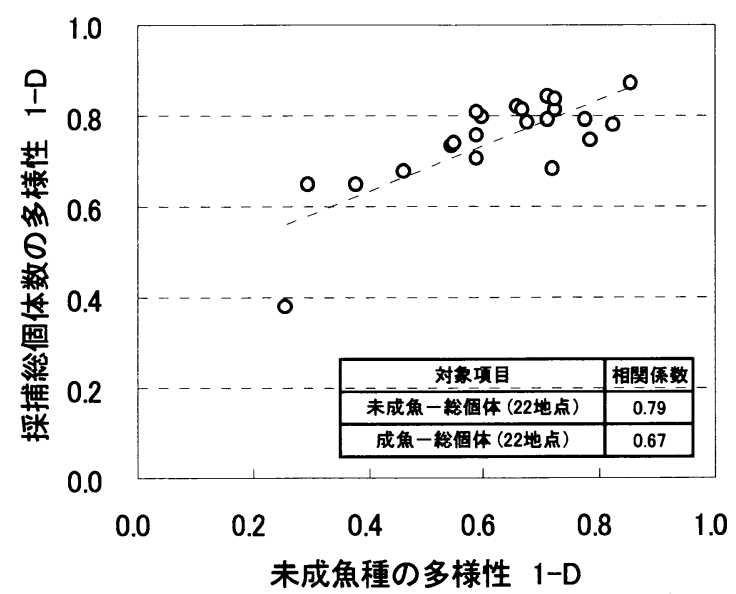

図一2. 未成魚および総個体数の多様性の関係

性が見られることが分かった.このことは，採捕魚種全 体としての多様性保全のためには，仔稚魚を含む未成魚 種の多様性の確保が重要であることが考えられる結果で ある. また，同図一2に，体長区分における成魚の多様 性と採捕総個体の多様性との相関性についても示したが, 未成魚の場合に比べ低いものであった. これらの結果に 着目し, 本研究では, 解析対象区間内での河道の物理的 多様性として断面内における水深と流速の標準偏差から 判断できる河床形態としての瀬・淵に加え, 仔稚魚期の 生息場として必要とされる河川水際域の評価についても 考察することにより, 生息魚種の多様性保全のために, より効果的な河道物理特性について検討していく.

\section{（2）河道の物理的多様性}

河道の物理的多様性に関しては，対象とする各河川に て実施された定期横断測量結果において, 河川水辺の国 勢調査の行われた時期および調查区間に該当する断面量 データと，同時期における各河川主要地点に設置される 水位流量観測所で測定された流量観測結果から得られる 時系列データとしての豊水・平水・低水・渇水流量を使 用した。 これら基礎情報から水位計算を行い, 四一-3に 示すように流下方向における水深と流速の断面内分布を

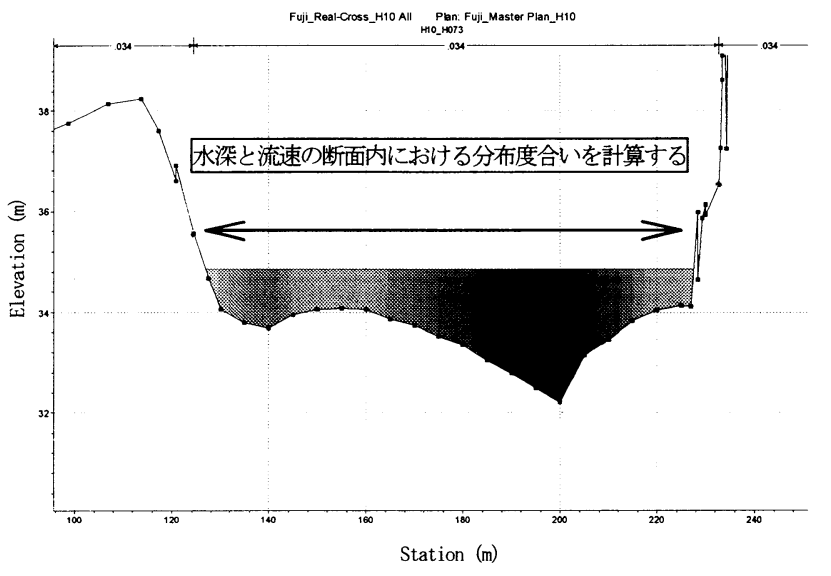

図一 3. 水位計算結果の一例 (断面図)
算出し，この結果のとり得る分布の度合いを表すために, 水深と流速に関する断面内標準偏差をもって, 河道の物 理的多様度を表す指標とした. なお, 解析対象とする河 道区間の流量設定については，水位流量観測所が最寄り に設置されていた場合は，そこでの測定結果をそのまま 使用した. しかし, 解析対象区間付近に観測所がない場 合は，その上下流における観測結果から予測した流量值 を使用した.この任意地点における流量設定方法の詳細 な手法については, 今後の課題としなければならない.

これらの計算条件に基づき，水位計算および河道の物 理的多様性算出結果の中から, 生息魚種の多様性と河道 の物理的多様性の関係を考えるうえで特徴的な結果であ る図一4〜一8を示す．なお，今回，図に示寸設定流量に 関しては，増减差の最も大きくなる，豊水・渴水流量に ついて解析した結果を中心に考察していく.また，図中 には，水深と流速の標淮偏差の意味を知る目的として， 各断面内における最深部河床高（標高）の檤断方向分布 についても示した.

\section{a）水深と流速の分布から見た瀬・啋構造}

これまでの富士川における研究では, 解析対象河道区 間における河道の物理的多様性としての水深と流速の断 面内標準偏差から，瀬・淵と判断できる構造を見ること ができた.つまり，断面内の水梁の分布度合いが大きく 流速の分布度合いが小さい淵と, 流速の分布度合いが大 きく水深の分布度合いが小さい瀬をグラフ上に表すこと ができ，また同時にこのような瀬・淵を有する河道区間 内には多様な魚種の生息を確認することもできた ${ }^{1)}$.

しかしながら，今回新たに解析対象に加えた河川での 同様の計算結果を見ると，これまでと同じ結果に至った 区間とともに，異なる結果が導かれた区間もあった。 図-4（区間記号 $\mathrm{T} 1$ ，飯田橋水神橋付近）および図 -5 （区間記号 T12，横川川合流付近）は，ともに天竜川上 流域での河道の物理的多様性を表した図である.この2 つの図より，T1区間は，河川距離標144.6〜145.2区間に 水深と流速に関する各断面内での標準偏差と最樑部河床 高の流下方向への分布状況から, 区間内の瀬・淵と判断 される構造を見ることができる，一方，T12区間の方は 対照的に, 水深と流速に関する標準偏差および最墚部河 床高の繸断（流下）方向分布にも起伏が現れていないこ とから，流れに変化のない一様な流況であると考えられ る.つまり，T1区間はT12区間に比べて，河道の物理的 多様性は高い区間となり，T12区間は河道の物理的多様 性の低い区間であるということになる．しかしながら， 両区間における生息魚種の多様性を見ると, それほど顕 著な違いはなかった．また，天竜川上流域内において， 相対的に生息魚種の多様性の低い值をとったT5 区間 (坂戸橋周辺) での結果を図一6に示すが，距離標169.4 付近に流速に関する多様性が上昇し, 瀬に分類されると 思われる場所が存在するが，その他の断面については T12 とそれほど大きな差は見られなかった。 

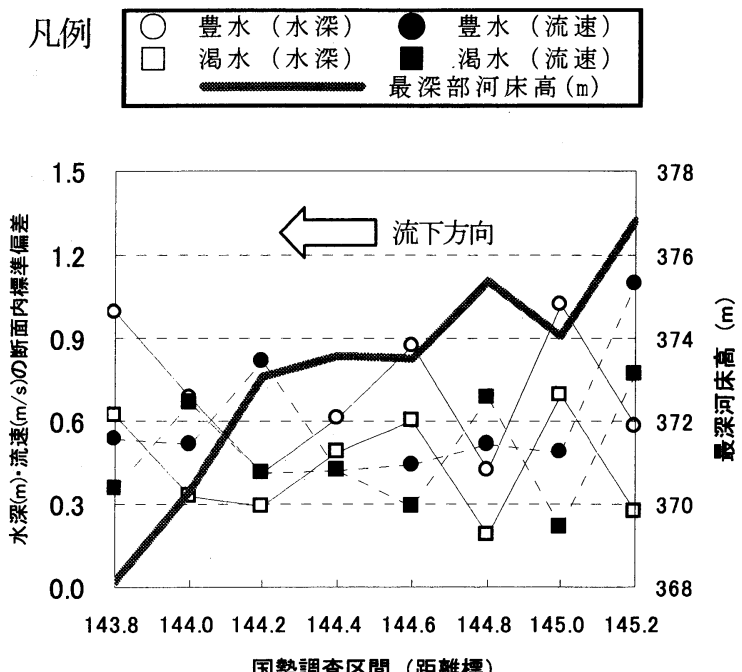

図-4. 河道の物理的多様性（T1，飯田水神橋付近）

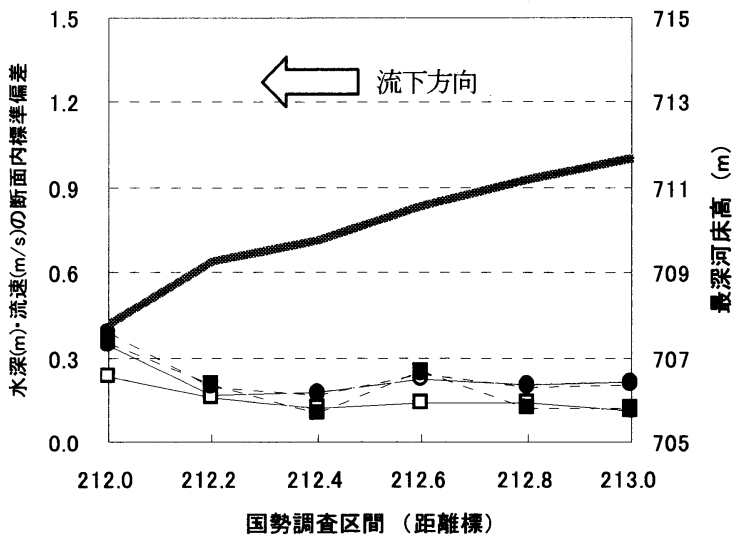

図-5．河道の物理的多様性（T12，横川川合流付近）

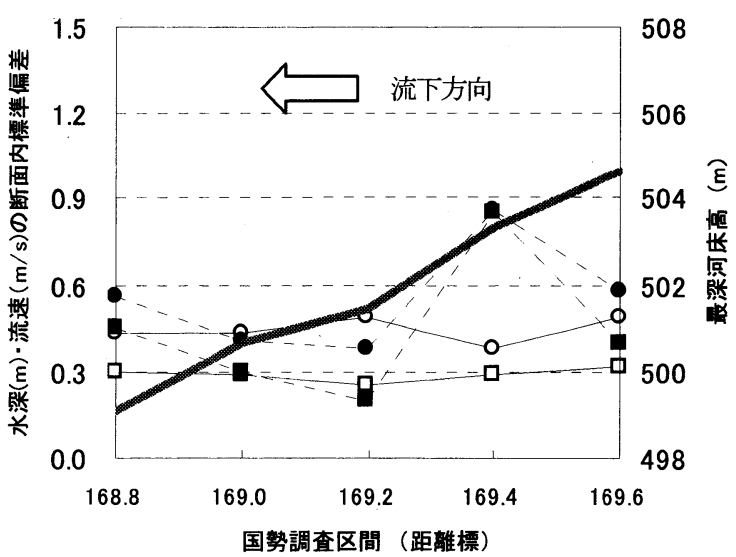

図-6. 河道の物理的多様性（T5，坂戸橋周辺）

このような結果は，河川の違いとは関係なく，いくつ かの他の解析区間についても当てはめることができたた めに, 太田川での同様の計算結果についても示す. 図一 7 (区間記号03，玫村）および図－8（区間記号04，共栄 橋付近）は太田川での計算結果である。これらの図から も，03区間内の距離標14.8付近に深掘れした淵と思われ る部分が存在し，その上流側にはそれほど卓越していな いが瀬と思われる場所が存在していることが分かり，ま
た一方で，04区間では，03区間で見られたような河道構 造は見ることはできず，両地点を比べた場合，明らかに 03区間の方が河道の物理的多様性が高い区間と判断され る. しかしながら，両地点における生息魚種の多様性で は，この場合もそれほど大きな違いを見ることはできな かった．ただ，富士川における解析で得られた結果に示 されたように，河道の物理的多様性の低い区間では，生 息魚種の多様性が低くなる場合もある ${ }^{1)}$.

つまり，今回，解析対象を増やし，複数の河川および 区間について富士川の場合と同様の計算をした結果，評 価対象となる河道区間内に瀬・淵と判断される構造が見 られ物理的な多様性が高い区間には，確かに多様な生息 魚種が存在しているが，一方で, 瀬・淵と判断できる構 造が見られず，比較的平坦な河道を有する区間において も多様な魚種の生息が可能であることが示された。この ことは，生息魚種の多様性を支える要因が，河道の物理 的多様性としての瀬・淵と判断できる構造の存在のみで はないことを表寸結果とも考えることができる.

よって本研究では, 最初にも触れたように, 生息魚種 の多様性に，より効果的に影響していると考える，未成 魚の多様性を支える生息環境として重要とされる河川水 際域の特性と生息魚種の多様性の関係についての考察し ていく.

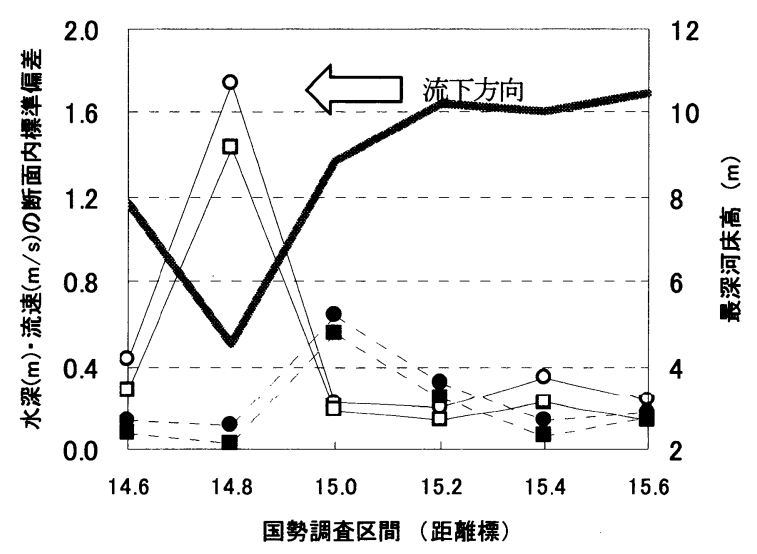

図-7. 河道の物理的多様性 (03，玫村)

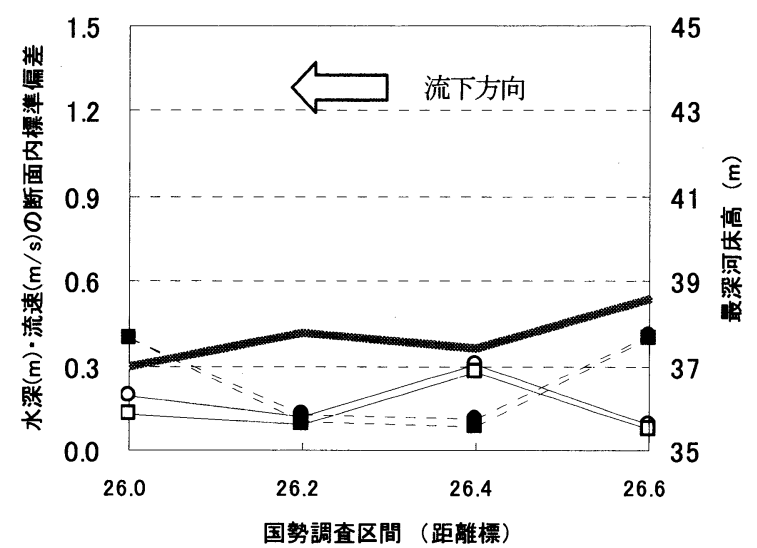

図-8. 河道の物理的多様性（04, 共栄橋付近） 


\section{5. 水際域の特性と生息魚種の多様性について}

水際域の特性と生息魚種の多様性について考える際に 重要となることの1つとして, 水際域をどのように定め るか，ということ，そして2つ目に，それをどのように 評価していくか，ということが考えられる．このことに 関しては, 水際域についてのより詳細な研究が必要とさ れると考えられる. しかし, 本研究では, 評価対象とす る河道区間のスケールとしては, 河川水辺の国勢調査実 施区間に相当する数百m 〜 約 $1 \mathrm{~km}$ 対象としているので, 微小な生息場の持つ物理的な特性に関しては考慮に入れ ていない，これらの考えを基本に，解析対象区間におけ る水際域の特性と生息魚種の多様性の関係について以下 に示した.

\section{（1）水際域の評価方法について}

上述したように，水際域を評価するためには，水際域 の取りうる領域を定める必要がある. しかしながら，こ れに関しては明確な数值として定めることは難しい。 こ こで本研究では, 次のような手順で水際域の取りうる範 囲を定め, その定められた領域と未成魚を中心とした生 息魚種の多様性に関する検討を行った。

まず，水際域を構成する物理要因については，これま でと同様に水深と流速についてから考えることとした. また, 水深および流速の範囲の設定に関しては, 既存文 献2，3）４）などから様々な魚種についての仔稚魚期に おける生活様式や主な生息場所を調へ，そこからいくつ かの範囲を与えることとした.

\section{a）水深の範囲}

様々な魚種の仔稚魚期を含む未成魚期における主な生 活様式について調べた結果, 全てではないものの, いく つかの魚種にとって水深 $10 \mathrm{~cm}$ 以下の環境が生息場所とし て適当であるとされていた ${ }^{3)}$. よって, 今回定める水際 域の範囲として，水深に関しては， $\mathrm{h} \leqq 10 \mathrm{~cm}$ とした.

\section{b）流速の範囲}

仔稚魚が選好性を示す流速に関しては，水深ほどはっ きりと数值上で表されてはおらず，「緩やかな流れ」と いう表現が使われることが多い，ここで，実際に，流れ の緩やかな場所で流下方向についての流速を計測してみ ると，限りなく $0 \mathrm{~cm} / \mathrm{s}$ に近いか，速くても $30 \mathrm{~cm} / \mathrm{s}$ を越 えるような流れはないと考えることができた．また，内 水面漁場環境の立場から見た場合，有機物の残渣などが 見られ一次生産性が高いとされる, 流速 $20 \mathrm{~cm} / \mathrm{s}$ 以下の領 域が重要であるとされていたことから ${ }^{4)}, \mathrm{v} \leqq 20 \mathrm{~cm} / \mathrm{s}$ を 水際域の流速の範囲とした。 よって，本研究における水 際域の持つ物理特性としての水深と流速の取りうる設定 範囲としては，水深h $\leqq 10 \mathrm{~cm} ，$ 流速 $\mathrm{v} \leqq 20 \mathrm{~cm} / \mathrm{s}$ と考え， このことと末成魚を中心とした生息魚種の多様性につい て以下に考察していく.

\section{c）水際域の評価}

富士川における研究では，水際域として水深 $\mathrm{h} \leqq 10 \mathrm{~cm}$ の領域の各断面および評価区間における広さについて触 れた ${ }^{1)}$ 。しかし，その広さのみに着目すれば，評価区間 延長に左右されるため公正な評価ができるとは考え難い. よって，今回は水際域として設定された領域が評価区間 内の水面の全表面積中に占名割合から詊他することに した. つまり，水際域とする領域が，年間を通した流量 変化（豊水・平水・低水・渴水流量）において，水面の 全表面積に対してどの程度の割合で発生しているかを計 算することで，水際域の評価とした。 これにより，国勢 調査の実施された区間における水際域評価の信頼性もあ る程度確保できると考える．以上のことより示される結 果としての図一9から分かることとして，太田川につい ては他河川に比へ，相対的に水面の表面積に占める水際 域の割合が高くなっている．しかし，全体的には約5\%前 後で推移している.つまり, 水際域の平面的な広さの割 合としては，全区間を通して，それほど大きな差はなく， 水面表面積の $5 \%$ 前後の微小な範囲で評価が分かれてくる

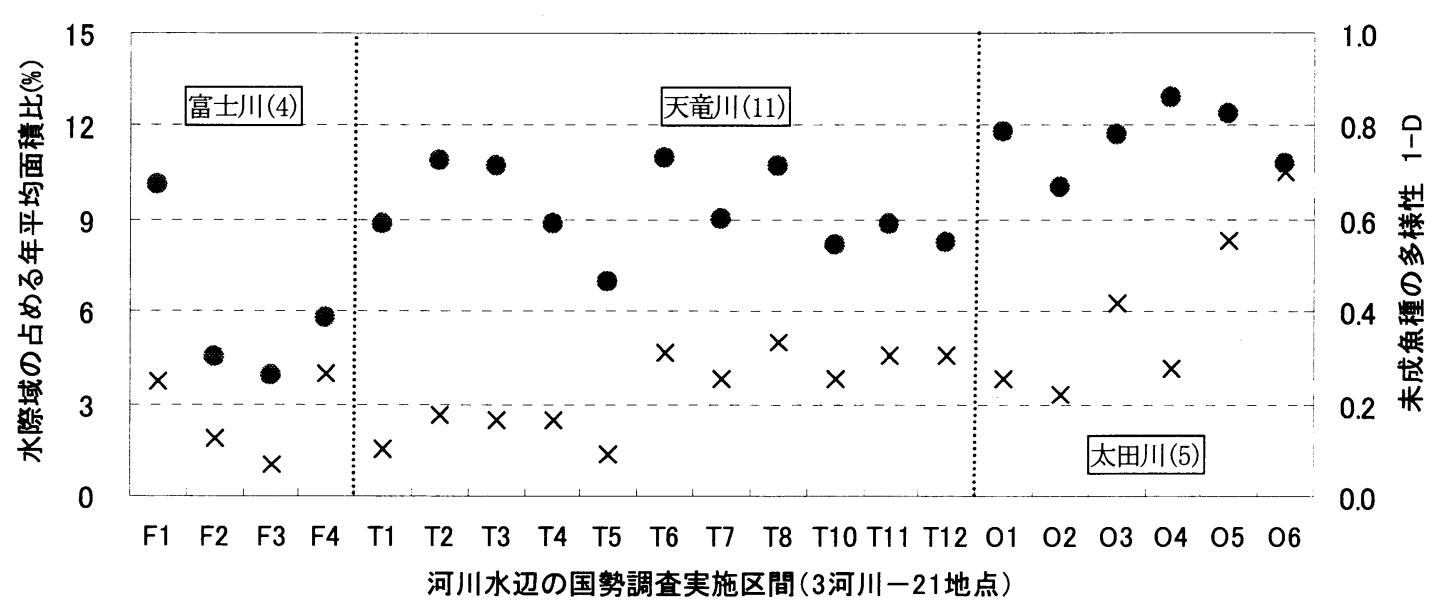

×水際域の占める面積比(\%) ・未成魚多様性

図－9. 解析対象区間における水際域の占める割合分布（年平均）と未成魚の多様性の関係 
ということが考えられる.これらの結果と, 未成魚を中 心とした生息魚種の多様性との関係を次に述べる.

\section{（2）水際域の特性と生息魚種の多様性の関係}

本研究では，水際域の特性と末成魚を中心とした生息 魚種の多様性の関係についての基礎的段階として，水際 域の範囲として設定した領域の平面的な広さの割合と生 息魚種の多様性との相関性を調べた。つまり, 評価対象 となる河道区間における生息場資源量としての水際域特 性が，生息する未成魚種の多様性を制限的に規定する要 因として考えられるのかを確かめることを試みた。これ ら両者の相関性を河川別に表した結果を図一10に示す.

この結果から分かることとして, 評価地点数に差があ るものの, 河川別にある程度のまとまりがあることが分 かる.これには，河川の地域特性などが影響しているも のと考えられるが，今回はこの詳細については考察して おらず, 今後, 具体的な水際域評価の際の課題としなけ ればならない上考えている. しかしながら，全体的に見 た場合，全水表面積中に水際域として設定された領域の 占める割合が $12 \%$ ては，未成魚種に関する多様性は相 対的に低く，5～6\%前後では多様性が高くなる傾向にあ ることが分かる，一方で，9１0\%前後からは，逆に多様 性が減少傾向にあるとも考えられる。つまり，今回のよ うに，一級河川における数百m〜 $1 \mathrm{~km}$ 区間を対象とした未 成魚種の多様性について，河川の地域性などの影響を考 慮せずに，その保全を考える際，水際域と設定される領 域の平面的な広さの割合として, 1 2\%では容量的に少 なめで，5～6\%前後程度の領域が確保されていることが 望ましい傾向にあることを示すことができた. このこと は，未成魚の多様性確保に限らず，全体的な多様性にも 繋げられるものである。一方で，10\%前後を境界に多様 性が減少に転じる傾向も示せた．しかしながら，この減 少守る傾向をより明らかに表すためには，多様性の低い 区間の評価の量を増やす必要があると考える.

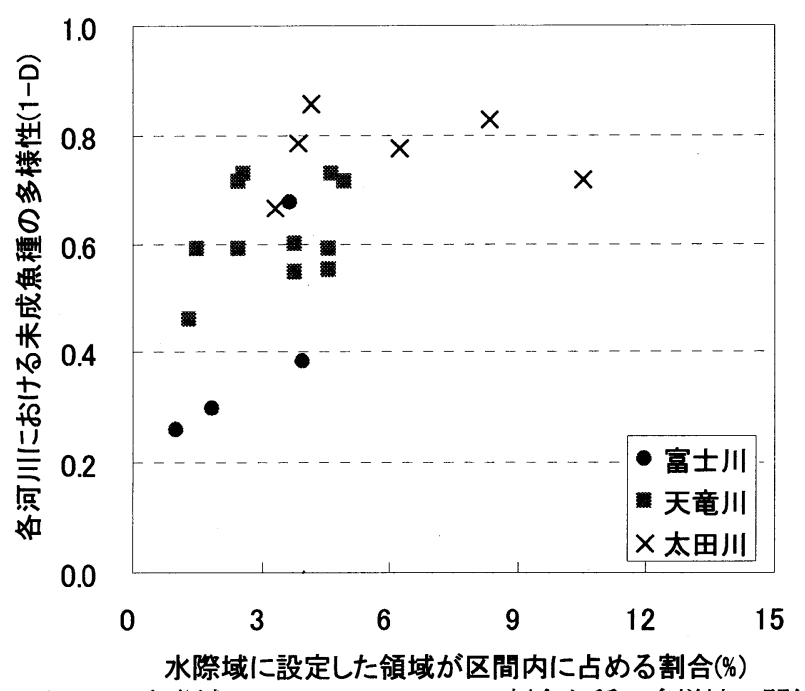

図-10. 水際域 $(\mathrm{h} \leqq 10 \mathrm{~cm}, \mathrm{v} \leqq 20 \mathrm{~cm} / \mathrm{s})$ 割合と種の多様性の関係

\section{7. まとめ}

本研究では，これまでの富士川を中心とした生息魚種 の多様性と河道の物理的多様性に関する検討 ${ }^{1)}$ に加えて, 解析対象河川および区間を増やすことによって, 効果的 で汎用性のある魚類生息場評価の確立を目指してきた. その主な結果は, 以下のとおりである.

(1)これまでと同様に, 評価対象河道区間内の各断面に おける水深と流速の分布の度合いから, 河道形態として の瀬・淵と判断できる構造を見ることができ, そのよう な構造を有する区間では多様な魚種の存在が確認された. (2)一方で, 瀬・淵と判断できる構造が見られない河道 区間においても比較的多様な魚種の生息が可能であった ことから, 魚類群集の生息場として, 瀬・淵以外にも効 果的な生息場があることも示された.

（3）この生息場として，仔稚魚種にとって重要な生息場 としての水際域の特性について考えた結果, その範井を 水深 $\mathrm{h} \leqq 10 \mathrm{~cm}$, 流速 $\mathrm{v} \leqq 20 \mathrm{~cm} / \mathrm{s}$ と設定した領域の平面 的な広さの割合が，仔稚魚期の魚類群集には効果的に影 響していることを示すことができた.

(4)今回は河川の地域性やそこに生息する魚類群集構成 種の違いなどについては考慮していないが，全体的な傾 向を把握することはできた. しかしこれらの問題は, 魚 類群集を維持するための正常流量に関する検討および評 価対象とする河道区間の空間スケールなどの問題と含め て今後の課題としなければならない.

謝辞 : 本研究を実施するにあたり,ご多忙中にも関らず, 資料提供ならびに様々なご協力を頂きました国土交通省 甲府河川事務所, 天竜川上流河川事務所および太田川河 川事務所の方々に，この場を借りて厚く御礼申し上げま す. また, 本研究の一部は, 河川環境管理財団の平成 15 年度河川整備基金助成事業の補助を受けて進められたも のであり,ここに媣く感謝致します。

\section{参考文献}

1) 砂田憲吾・川村和也 : 河道の物理的多様性と生息魚類の多様 性に関する基礎的研究，河川技術論文集，第9巻，2003年6月， pp. $415-420$

2) 社団法人日本水産資源保護協会: 漁場保全機能定量化等事業 「環境が河川生物および漁業に及ぼす影響を判断するための 判断基準と事例」, 平成6年3月

3) 宮地傳三郎 - 川那部浩哉・水野信彦 : 原色日本淡水魚類図鑑, 保育社，1996年

4) 社団法人日本水産資源保讙協会: 漁場環境影響評価事業「漁 場環境影響評価技術指針（内水面編）」，平成11年3月

(2003. 9. 30受付) 